\title{
MINARETS AS A VITAL ELEMENT OF INDO-ISLAMIC ARCHITECTURE: EVOLUTION AND MORPHOLOGY
}

Received September 28th, 2019 | Accepted March 4th, 2021 | Available online June 15th, 2021 |

DOI http://dx. doi. org/10.18860//ia.v6i3.7711 |

Mohammad Arif Kamal

Aligarh Muslim University

Aligarh, India

architectarif@gmail.com

\begin{abstract}
The Minarets are a distinctive architectural feature of Islamic Mosques. The Minarets have become an essential and integral part of the mosque in the Indian sub-continent as like anywhere in the world. The Minarets evolved in Islamic Architecture at very early times. Although it was not an essential part of the mosque during the lifetime of the Prophet Muhammad $(\mathrm{PBUH})$ and even for some time after the period after him. There are, however, many conflicting views as to exactly where, when and by whom were the first minarets built. The minarets were constructed for monumental purposes but became symbolic and became the permanent features of the mosque buildings. These minarets are being built in varied geographical and cultural environments. The Muslim architects used forms that have been acclimatized in their traditional cultures. The architects did not invent new forms but preferred to refine the existing ones with the highest proportion and integrity to the main building. Therefore, they had gone through a transition state in adapting the minarets form, keeping their cultural richness and transforming them into a religious identity most suited to the Islamic buildings. This paper reviews the mosque architecture in general, the various functional aspects of minarets, its evolution in history, and the forms that the architects in India had used to determine their roots and the process of transformation by which it had been recognized as a vital element in the Islamic buildings, especially the mosques.
\end{abstract}

KEYWORDS:

Minarets, Mosques, Evolution, Islamic Architecture, India

\section{INTRODUCTION}

Many different types of buildings represent Islamic architecture in India. These are two common categories of Islamic Architecture religious and religious. The religious one consists of only two types: a mosque and a tomb. Landforms are those designed for public and social purposes. The mosque or masjid, literally "the place of worship," is not only the most crucial building of faith but also the key to style. It was a kind of complete novel structure, orinitially developedy the Prophet Muhammad (PBUH) in Arabia in a va straightforwardy. It was near the compound of the Prophet's house (PBUH) in Medina, a fenced courtyard with small rooms on one side and an ugly porch on the other side [1]. Later, it turned into a rectangular open space or 'Sahn' (yard), four sides closed with looted cloisters or "Iwan" with a fountain or tank in the middle of the bathroom.

The cloisters towards the Makkah direction 'Qibla' of the courtyard were expanded and elaborated into a pillared hall or Sanctuary. A wall at the back containing a recess or alcove called a 'Mihrab' indicating the Qibla or direction for prayer. To the right of the Mihrab stands the 'Mimbar' or pulpit. Part of the Sanctuary is closed to the women's room. A high platform, where the host recites 'Azan,', or recites prayers, is also a necessity and often takes the form of a high tower called 'mina.'t'. This symbol of Islamic architecture has been a part of Islamic history since the eighth century A.D. From this point on, the minaret became a continuous Islamic practice in many parts of the Muslim world and eventually spread to regions where it had previously been rare. It became an integral part of Islamic architecture and is still considered suitable for mosques because of its symbolic meaning [2].

\section{EVOLUTION AND HISTORICAL DEVELOPMENT OF MINARETS IN ISLAMIC ARCHITECTURE}

Admittedly, the ancient Islamic church of Islam had no minaret at all. Early Muslims came to Medina, worshiping outside the first adhan. Still, Muslims heard Jews using the horn (Shofar) in certain ceremonies and Christian Nukus or clapper (a long piece of wood beaten with a flexible wabil), demanding something equal to their use [3]. One of the Prophet's friends suggested using a human voice, and after much deliberation, the Prophet Muhammad confessed and issued the command "Arise, Bilal, call for prayer." Tradition adorned this simple account and was later translated as going to a prominent place and being called to 
prayer [4]. It was natural for Bilal to use a position where he could be seen and felt better. The Islamic church built in the days of the Prophet Muhammad in Kuba and Medina was so simple that there was no place to build anything like a tower, even if the necessary means and skills were available. In the Hadith, the Muslims of Medina are called to prayer on the Prophet Muhammad's house [5].

Minaret (derived from the Arab manif rat scale; manar or minar is the Arabic house of a lamp tower where fire, fire) is a high and unique turret of Islamic art. This form is based on the case of Pharaoh, the great lighthouse of Alexandria, on the upper floor where the seventh-century Mohammedan conquerors set up a small prayer room. The lighthouse form is practiced in the hills found to be attached to Muhammad's mosques and has probably been a significant factor in converting the Christian church tower [6]. The minaret is usually square from the bottom to the height of the mosque's wall to which it is attached and is usually octagonal above. The upper part is divided into two or three sections. The upper floor wall is turned back to the lower one, accepted on the small balcony, where the azan, or call for prayer, is sung by Muezzin. To give a broader range to the balcony, a stalactitic vaulting was removed. Stone balloons surround the balconies, and the upper floors are richly decorated; a small bulbous dome conquers the upper floor.

Apart from other works and for centuries, a minaret was used as an essential object for Muslims. It seems, however, that in general, it has nothing to do with azan's work as the call to prayer can be made sufficiently on the roof of the mosque. The biggest problem we face in dealing with the minaret is how and when it acquired its status because summoning the faithful in prayer, probably as old as the construction of the Prophet in Medina, initially took place on the streets from the highest roofs of neighboring houses. During the Prophet Muhammad's (PBUH) lifetime, the invitation to prayer was made in this way, and the practice continued in another generation [7].

The philosopher Walid (A.D. 705) constructed the earliest known minaret in a mosque in Damascus, Syria (Figure 1). The oldest surviving mosque on the Iberian Peninsula in Spain in Cordoba, founded by Umayyad amir 'Abd al-Rahman-I (756-788). The mosque (Fig. 2), completed in 786-787, measured approximately 74 square feet and had an open courtyard preceding the hypostyle prayer hall on its roof supported by an emerging dual-service system. At first, the mosque had no place for adhan or to call a prayer; people are called to a higher place in the (administrator) residence near the mosque [2]. The minaret of the Great Mosque of Kairouan, Tunisia, was erected in 836 A.D. The first floor, 18 feet [ $18.90 \mathrm{~m}$ ] long and 10 feet $[10.70 \mathrm{~m}]$ wide, is about two feet [50 $\mathrm{cm}$ ] high. Samarra's Great Mosque, built inside 848 A.D. at one time, was the largest in the world (Figure 4). Its minaret, the Malwiya Tower, is a huge fiery mound 52 feet [52 $\mathrm{m}$ ] high and 33 feet [33 m] wide with a windshield [8]. The next day is the minaret of the Islamic church of Tulun, Cairo (A.D 879), ascending the exterior flight of stairs resembling 'viewing towers' in the construction of Assyrian buildings (Figure 5). This minaret was inspired by the Minaret of Samarra [9]. Later, Muslim communities began building minarets as part of Islam.

In Central Asia, towers were erected as a tradition going to pre-Islamic times. Forms used in the towers built by the Buddhist Kushans in Central Asia, or similar forms found in an area that later became Islamic Territory, may have been introduced. Minars, towers, columns, and matching high erections become standard features in Islamic Architecture, particularly in Western Asia, where pillar-like Minars are often found in the vicinity of many towns. Most of these are built of bricks or rubble and are round in section.

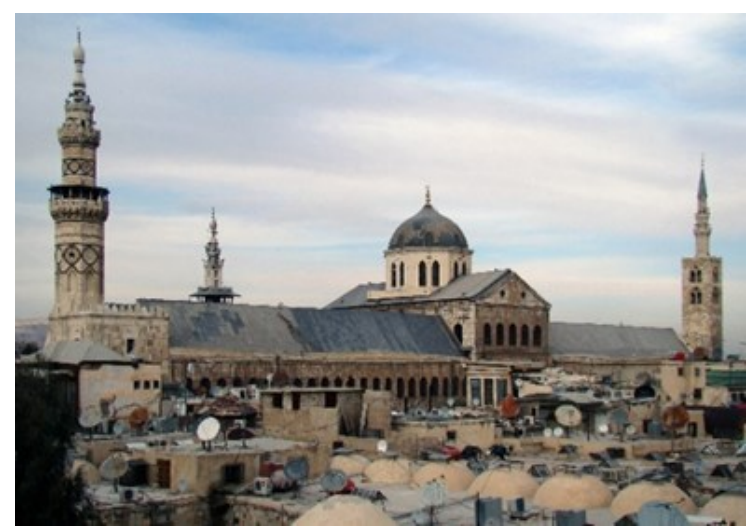

Figure 1. Early Minarets at Great Mosque of Damascus, Syria (705 A.D.)

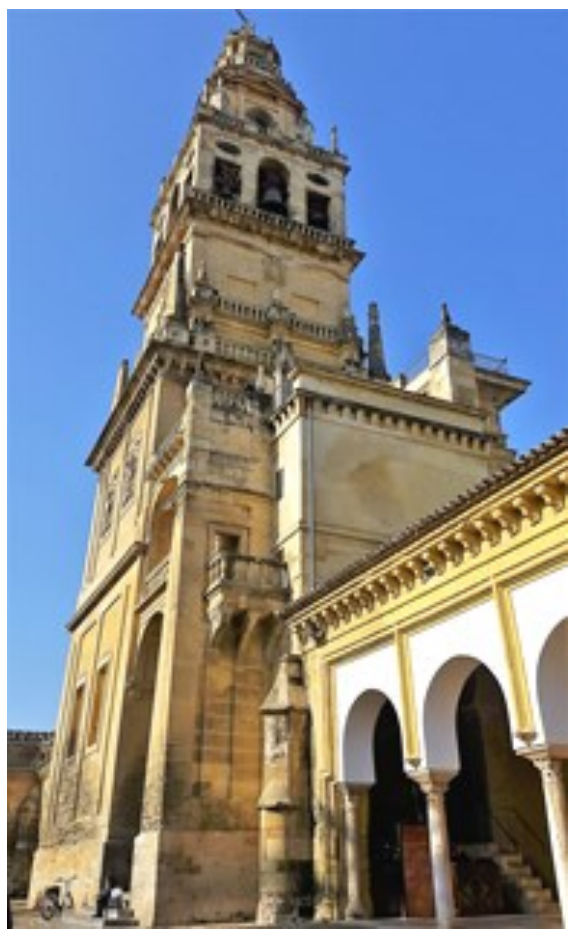

Figure 2. Early Minaret of Mosque of Cordoba, Spain (786 A.D.) 


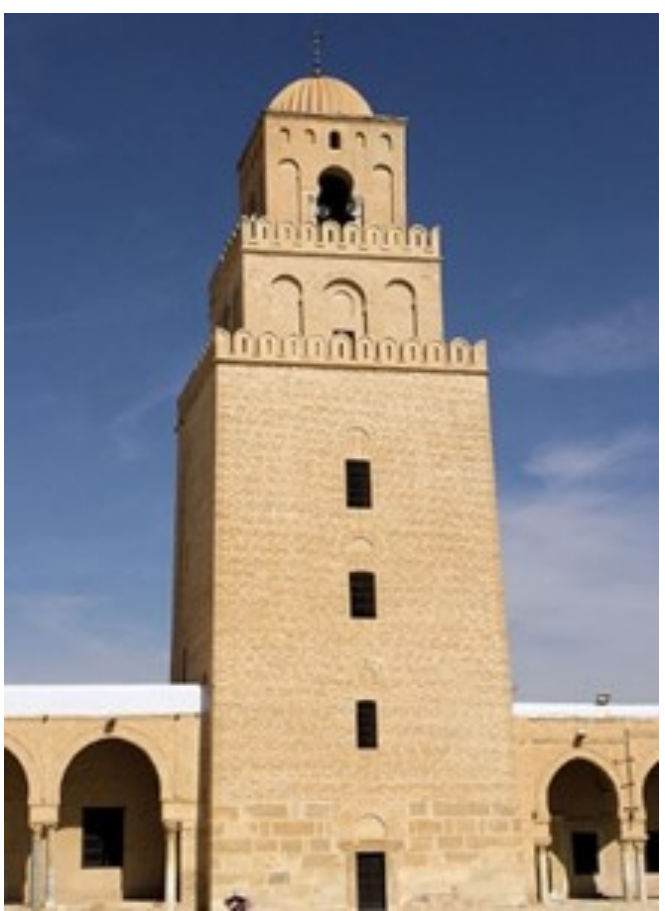

Figure 3. Minaret of Great Mosque of Kairouan_Tunisia (836 A.D.).

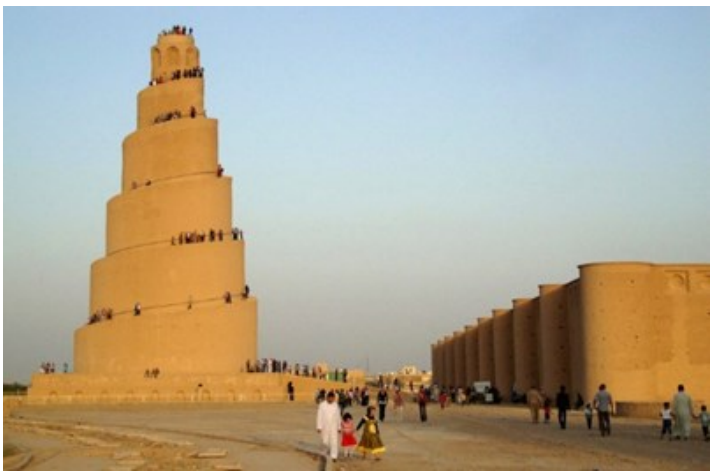

Figure 4. Spiral Minaret of Malwiya Mosque at Samarra, Iraq (848 A.D.).

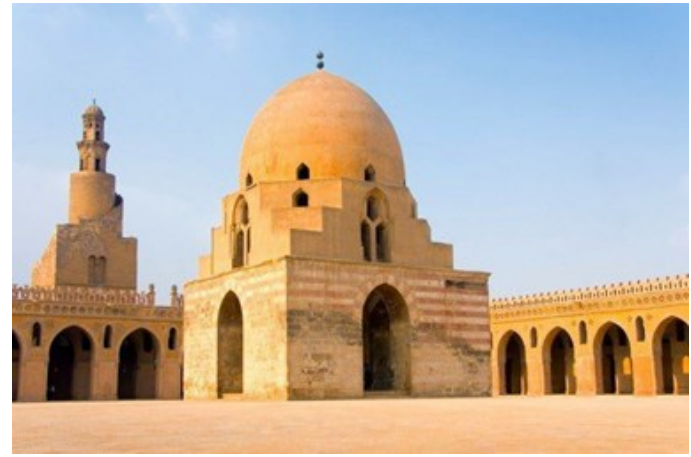

Figure 5. Early Minaret of Ibn Tulun Mosque Cairo, Egypt (879 A.D.).
THE MINARET AS METAPHORICAL INSIGNIA IN ISLAMIC ARCHITECTURE

Minaret as a 'tower,' a structure longer than its base, built-in response to security and communications problems, has represented domination and power throughout history. In the case of Islamic civilization, the ideal structure that indicates the existence of Islam is the minaret, whatever its current occupation and what possible social reasons led to its formation. The minaret is a prominent feature of the mosque, used mainly for prayer. The minaret, the tower on which the Muezzin seeks five daily prayers, serves as a symbol of the Islamic mosque because it separates the building as a place of worship. Initially built for a prayer call in the past, mine is not needed today due to technological advances. The towers were constructed to serve as 'world symbols of Islam' - to be seen from afar and seal a Muslim personality site. Since its appearance figure stands more freely or longer than any connected support structure, minarets provide community focus and serve as a local symbol [9].

Minaret as a symbol represents the multiplicity of principles, the system of values, knowledge, culture. From the $13^{\text {th }}$ century onwards, in particular, they became the hallmarks of Islamic conquest. India's first Muslim church, Quwwatu'I Islam (The Might of Islam), was founded by Qutb-ud-Din Aibak in 1193 A.D. in Delhi. It was intended to serve as a duplicate function - both as a mosque minaret and the most visible symbol of the growing power of Qutb-Aibak and Islam. There were two ways to strengthen the military and theocratic power. Once the military objectives were achieved, Qutb-ud-Din began to manifest himself as an aggressor and a missionary who converted people. The Qutb Minar, $72.5 \mathrm{~m}$ high, is the tallest stone tower in the world [10]. The minaret shows the importance of the Islamic church. When Sultan Ahmad decided to provide six minarets for his mosque in Istanbul, the six minarets of the Mecca temple had to be raised to seven, looks like a celestial being [11] "from heaven and earth" and is denoted by the Arabic letter alif, a straight line [12].

\section{EVOLUTION OF ISLAMIC ARCHITECTURE IN THE INDIAN SUB-CONTINENT}

The formation of Islam on the continent below can be solved in three main stages: Delhi or Imperial, Provincial and Mughal. The most notable change in the Indian subcontinent brought by the Turks was introducing a new architectural style, which was common in the mosque. The Turks also introduced Arab and Persian architectural traditions, especially the latter. They bring features such as a pointed arch, a flexible vault, a dome, and an octagonal structure under the dome. All of this was new to Indian Architecture. The Imperial style was introduced under the rule of Qutb-ud-Din Aibak when essential building techniques began. The style was continued by Al-Tutmish, who can be seen in the buildings he built. After the death of Al-Tutmish, except for the brief period of Balban's reign in the vital appearance of the real arch, no structures were made 
until the rise of the Khaljis. About the third quarter of the century, little progress in Islamic Architecture was made. Imperial Architecture changed Tughluqs' rule. The simplicity of the lines, the reduction of decoration to a minimum, and the use of large stone blocks were all combined to produce strength and strength [13]. The Lodhis are returning to a more elegant style. The walls of their buildings were overcrowded, which made it difficult to determine whether the balance of the dome should lie in proportion to the height and size of the exterior or interior. The use of a double dome solved the equality problem. They also began decorating their buildings with borrowed Persian tiles.

The Provincial construction was developed simultaneously as Delhi/Imperial, with local changes often available to acquire building materials. It was particularly so in Bengal when a stone was scarce, and bricks were widely used. The decorative work of Terracotta, commonly used in Buddhist temples, has continued to be used in temples and other Islamic architecture. The construction of buildings in Gujarat and Malwa has achieved a high level of beauty because the traditional culture lived here more than elsewhere. The impact of the new facilities has also been felt in Rajasthan, where the home's construction shows little confusion outside. The third style, Mughal, was the latest and most mature form of Indo-Islamic architecture. It emerged in the mid-sixteenth century and continued to prosper until the eighteenth century, when the dominion of the "Great Mughals" began to decline. The mughal architecture was based on three primary sources: indigenous Indian Islamic, Persian Central Asia, and local Hindu architecture. The distinctive features of Hinduism included in the Mughal architecture include the construction of tarlatan stones, pipes and columns richly carved, and shallow arches made of corbel rather than voussoirs. In addition, there are architectural structures often associated with Hindu buildings, including Chatris, Chajjas, and Jharokas, which became symbols of Mughal architecture. Chatri is a ruling Kiosk resting on pillars used in the construction of Hindus used as a cenotaph. Still, it is placed as a decoration on mosques, palaces, and tombs [14].

\section{EVOLUTION OF MINARETS IN THE INDO-ISLAMIC ARCHITECTURE}

Qutb Minar in Delhi was the first and foremost tower built to commemorate the Muslim conquest of the battlefields in 1193. It also formed the integration of the Islamic church into the Arab tradition of monuments attached to mosques. It is believed that the Ghaznavid mine near Kabul and Jam may have suggested the construction of Qutb Minar (Figure 8). Jam minaret is located in a remote and inaccessible area of Shahrak district in Ghor province, near the Hari River (Figure 6). The 65-meter-high minaret was built around 1190 AD, all baked bricks, and is famous for adorning bricks, stakes, and glittering tile ornaments, consisting of Kufic and Nakshi calligraphy groups' geometric patterns verses from the Quran [15].

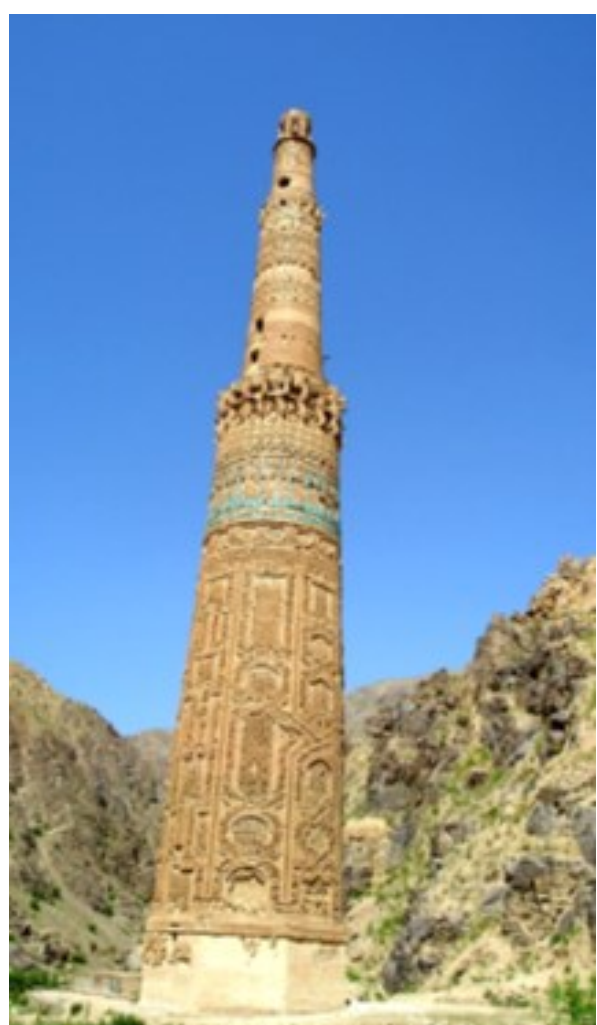

Figure 6. The Minaret in Jam, Afghanistan, was built around 1190 AD.

The construction of the Qutub Minar was made possible by the inspired vision of Qutb-ud-din Aibak and was recognized by the creative ingenuity of the Indian workers (Figure 7). It was located to the left of the main entrance, outside the mosque. Later, the mine was not separated but attached to a large building and had the same area as the minarets in other early mosques and became part of the construction program. The Qutb Minar comprises a tall tapering cylindrical tower standing on a four-story base at the height of 72 feet. $5 \mathrm{~m}$. The width of the bottom of the Minar is 14.3 meters, and the upper floor measures 2.7 meters wide. Each floor is accessed by an indoor spiral staircase leading to balconies supported by muqarnas corbels.

The Qutb Minar has five separate floors, which were renovated and added several times by successors. The lowest is the circular and the smallest triangular, the second and the third triangular, while the fourth and fifth are very clear. Each floor is exposed on the balcony, revealing a system of stalactite pendentives - this feature first appeared in India and has no doubt been introduced from the earliest Islamic architecture [10]. The element of the Minar is the angular and circular wires in the hole. The upper floor was constructed of circular teak with openings for windows and an interior roof that crowned the entire building. The sculpted treatment of the lower extremities on the balcony reflects the graduation of a Hindu sculptor in Islamic sculpture. 


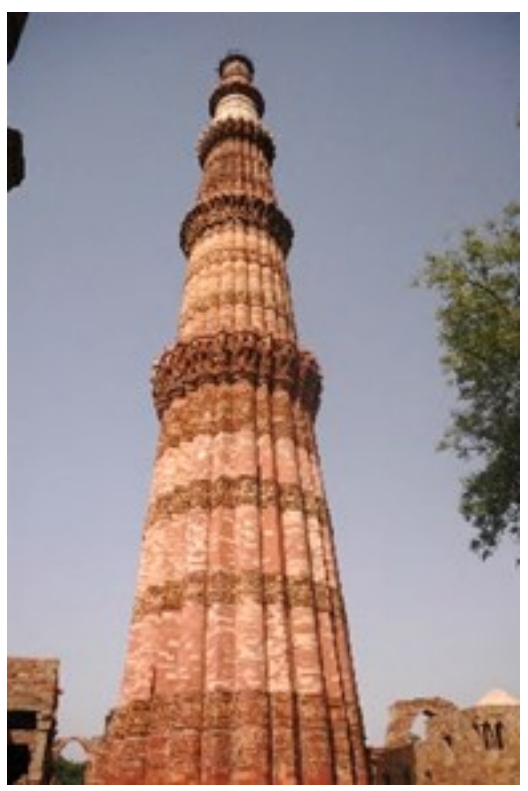

igure 7. Qutub Minar with fluted pillar shaft, inspired from Jam Minaret (1193 AD).
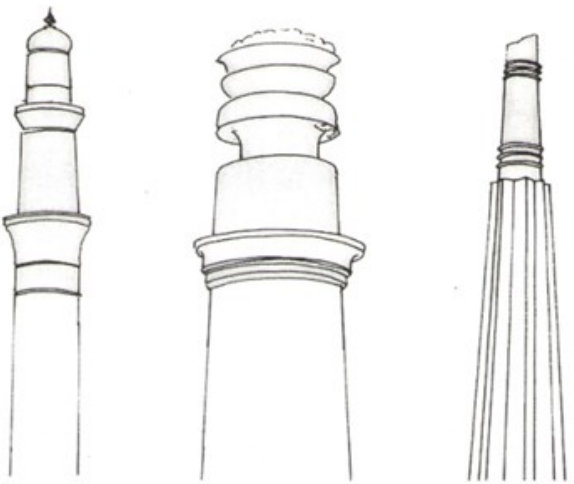

Figure 8. The similarity of details of the early tower at Kabul with Minars of India.
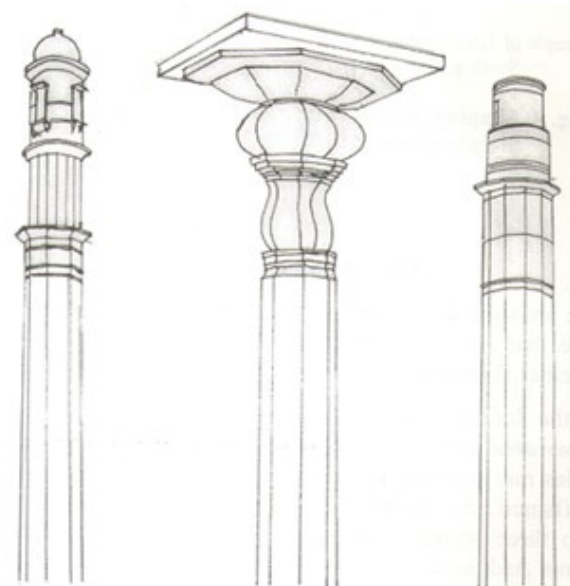

Figure 9. Comparison of $10^{\text {th }}$-century pillar, Koryangula with the Islamic Minarets.
A circular tower at Gaur, Bengal, called the Firuz Minar, has been erected to serve the two purposes: a tower of Victory and a minaret for the call to prayer, on the same principle as the Qutb Minar at Delhi but to a much smaller scale. It has five stories, the three lowest being twelve-sided while the two uppers are round. Minarets were also used to flank entrances. Tapering cylindrical minarets on the polygonal plinths was commonly used. In some of the Mughal mosques, minarets are used to stress the four corners of the Sanctuary.

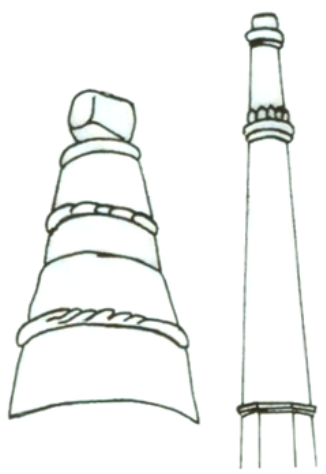

Figure 10. Shaping of the minaret from conjectural Steeple of South India.

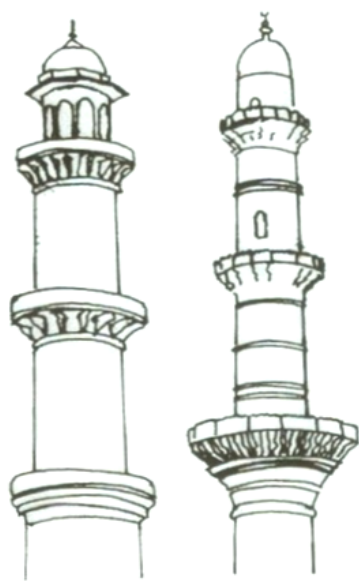

Figure 11. Minarets of various designs and forms.

The most common form of minaret comprises a heavy cylinder resting on a high polygonal plinth and horizontally articulated annular moldings, balconies, and niches. The minaret often included a massive polygonal lower story serving as a buttress, crowned by a slender shaft or as, in the later stages, by an open turret, dome, or Kiosk (Fig. 11). In such cases, while retaining religious significance, the minaret was used primarily as an articulating element [5]. 


\section{TRACING THE ROOTS OF MINARETS IN INDIA}

The mosque is, of course, the principal religious buildings of Islam. As a result, this is the building type that most frequently reflects the impact of many distinct local architectural traditions, shaping Islamic architecture. The earliest example of Mosque architecture is the Quwwat-ul-Islam mosque a Delhi. There is no doubt that the two different styles merged, although not entirely, and this merging was mainly due to the employment of Indian artisans. As mentioned earli$\mathrm{er}$, the Islamic architecture of the Indian sub-continent can be divided into three styles: Imperial, Provincial, and Mughal. Several minaret forms had been employed from the Qutb Minar and used, mainly, onto the mosques. There is no doubt that the Muslims invented many minaret types, but it took them years to gain skills in minaret design and construction.
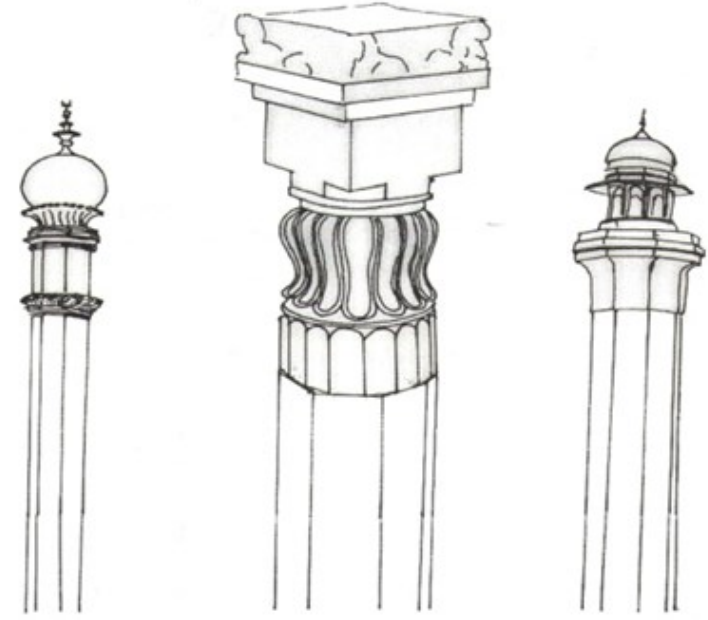

Figure. 12 Octagonal minarets in India may have been derived from the octagonal shaft at Sanchi.

In investigating the roots of pillars in the Indian sub-continent, we have to go way back to the $3^{\text {rd }}$ century B.C. During the Ashokan era, lofty pillars were raised for commemorative and political purposes (Fig. 12). Some of these pillars, some of them as much as fifty feet high, were distributed over a wide area. Each pillar consisted of a plain un-ornamented shaft, circular in section, thirty to forty feet high, rising straight out of the ground without any suggestion of a base, and tapering like the trunk of a tall palm tree [16]. Fluted pillars with capitals were also erected at the entrances of important buildings. In the later style, pillars of the octagonal shaft were also developed. These symbolic pillars with tapering shafts continued to be used in the rock-cut style of architecture during the Hinayana and later periods (Fig. 9). On the different relevant form, recorded in the $8^{\text {th }}$ and $9^{\text {th }}$ centuries in Minya Konka and Chotski in eastern Tibet is a stellate watchtower, some 59-62 ft. high, which reproduced the form of the otherwise virtually unparalleled $12^{\text {th }}$-century minarets of Ghazna [17]. The vertical sikhara, or tower, made an obvious contrast with the low, flat rooflines of the average Indian village. In northern India, the shikhara is very dominant. It is conical in for, with convexly curved sides: and there is usually a final of the vase or 'melon' form. Chatris, or umbrellas (kiosks), over the rounded, octagonal, and in some cases over the squarish towers, are the widely used minaret forms of today's mosques in India (Fig. 10).

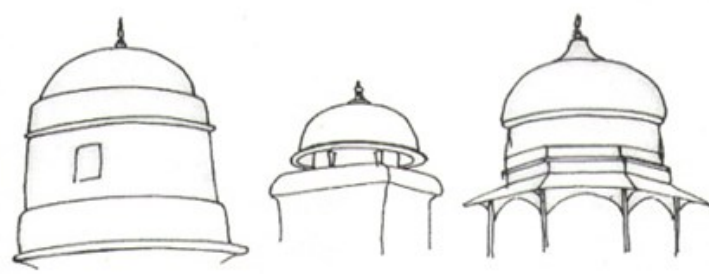

Figure 13. Adaptation of chatri into minaret's domical kiosk.

\section{CONCLUSION}

There is no doubt that the shapes and forms of minarets differ throughout the Islamic world. Their shapes were quite different in the eastern Islamic world. Instead of a square shaft, they built cylindrical, upward tapering tall towers with one or two balconies covered with Chatris/Kiosks on top (Fig. 13). These minarets have greatly determined the shapes of the subsequent minaret in India and around.

Muslim Architecture entered northern India from Persia via Afghanistan. The Turks, who brought with them Arab and Persian architecture traditions, were well aware of the minaret construction. Although Muslims did not invent the minaret, they were already familiar with it and applied it as an element to their mosques. It is also a fact that in the Indian subcontinent, the vast majority of the Muslims were Hindu converts. They were trained builders of stone and skilled craftsmen. Many minaret shapes and forms had already been in use for centuries. This simplified the construction problems of the Muslim rulers and builders in the Indian sub-continent. Their flexibility in adopting the local forms, construction materials and techniques, and the readily available craftsmen made their job easier. It is also a fact that, traditionally, the minarets used to be erected as symbolic elements in the buildings by the local peoples. But Muslims used them extensively as essential elements in their mosques. No doubt that, in India, not all the previously existing minaret forms were adapted and transformed. However, parts of the minarets, such as shafts (mostly rounded and octagonal) and domed Kiosks (Chatri), have been adjusted so successfully that the minaret became a symbol of Islamic architecture whether used separately or attached to the mosque. That is why, today, none of the mosques is seen without minaret (s), and it has turned into a vital and symbolic element of Islamic Architecture. 


\section{REFERENCES}

[1] B. Fletcher, A History of Architecture on the Comparative Method, $17^{\text {th }}$ Edition, London: The Athlone Press, 1963.

[2] O. Urey, "Transformation of Minarets in Contemporary Mosque Architecture in Turkey," International journal of Science Culture and Sport, vol. 1, no. 4, Jan. 2013, doi: 10.14486/ IJSCS36.

[3] Muslim, Al-Sahih, Delhi, 1309.

[4] Zain, Al-Abidin, Al Bahr al Ra'ik, p-268.

[5] R. Hillenbrand, Islamic Architecture, Form, Function and Meaning, Edinburgh: Edinburgh University Press, 1994.

[6] J. M. Bloom, "Creswell and the Origins of the Minaret", Muqarnas, Vol. 8, 2001

[7] J. M. Bloom, Minaret: Symbol of Islam, Oxford: Oxford Studies in Islamic Art 7, 1989.

[8] Admin, "Great Mosque of Samarra in Samarra Iraq," Beautiful Mosque Gallery. https:// www.beautifulmosque.com/Great-Mosque-ofSamarra-in-Samarra-Iraq (accessed August 30th, 2019)

[9] "Mosque of Ibn Tulun," Trips in Egypt, Decem- ber 20th, 2018. https://www.tripsinegypt.com/ mosque-of-ibn-tulun/ (accessed May 27th, 2021).

[10] A. Nangia, "The Towers of God," October 31st, 2001. https://www.boloji.com/articles/928/thetowers-of-god (accessed August 14th, 2019).

[11] L. Bernard, Islam and the Arab World, New York: American Heritage Publishing Co., Inc., 1976.

[12] P. Johnson, Civilization of the Holy Land, London: Weidenfeld and Nicolson, 1979.

[13] R. Thapar, A History of India, Part-1, U.K.: Hazell Watson \& Viney Ltd., 1976.

[14] A. Peterson, Dictionary of Islamic Architecture, New York: Routledge, 1996.

[15] R. P. Wilson, "Ghaznavid and Ghūrid Minarets," Journal of the British Institute of Persian Studies, vol. 39, no. 1, pp. 155-186, 2001.

[16] P. Brown, Indian Architecture (Islamic Period), Bombay: D.B. Taraporewala Son \& Co. Pvt. Ltd., 1981.

[17] S. Grover, The Architecture of India: Islamic. New Delhi: Vikas Publishing Private, 1981. 